\title{
The Convergence Path of the Income Gap between Urban and Rural Residents under the Background of New Urbanization in China
}

\author{
Chi Zhang ${ }^{1, a *}$ and Xiaoli Duan ${ }^{2, b}$ \\ ${ }^{1}$ International Business Administration School, Shanghai University of Finance and Economics, \\ Shanghai, China \\ ${ }^{2}$ School of Economics \& Management, Zhengzhou Normal University, \\ Zhengzhou, Henan Province, China \\ a83599314@qq.com \\ bdxly205@126.com
}

\begin{abstract}
Keywords: New urbanization; Income gap between urban and rural residents; The convergence path
\end{abstract}

\begin{abstract}
In recent years, the income gap between urban and rural residents in China is quite prominent. From the perspective of urbanization the reason is that the alienation of urban expansion leads to the urbanization of the land before urbanization and the lack of farmers' participation in exogenous urbanization. The paper analyzed the mechanism of income gap between urban and rural residents in the process of urbanization. From the aspects of reform of land circulation system, the improvement public services level and the enhancement farmers' quality, the paper puts forward the urbanization development model and the convergence path of the income gap between urban and rural residents under the background of new urbanization.
\end{abstract}

\section{Introduction}

Over the past 30 years of reform and opening up, China has undergone rapid urbanization and a drastic social transformation. On the one hand, with the rapid economic development and pushing forward urbanization, more and more non-agricultural rural residents were employed non-agricultural sector in the city, the living standards of urban and rural residents has been rapidly increased in china. On the other hand, from the transition of planned economy to market economy in china, most of local government attach importance to "land urbanization" which focus on exploitation of real estate, and neglected industrial urbanization and human urbanization, it also objectively promoted the expansion of urban-rural development gap and income gap. By the end of 2016, the Gini coefficient of china's household income has risen from 0.3 at the initial state of reform and tacked to 0.465 [1], Considering the factors of the living environment and social security, the urban-rural income gap has become more obvious. "Decision of the Central Committee of the Communist Party of China on several important issues of deepening reform" proposed that the achievement of the reform and development should benefit the entire people more fairly and reflect the great importance attached by the Central Committee of the Party to the issue of social equity.

With urban scale expansion and the increasing use of urban construction land, land reallocation had begun between countryside and urban areas. Low price of agricultural land caused the loss of land capital infringed upon the basic rights and interests of farmers, which increase the income gap between urban and rural residents. Urban-rural income ratio in China has also been expanding since the reform and opening up, which increased from 1.86:1 in 1985 to 2.72:1 in 2016. [2]

\section{Literature References}

Why is the income distribution gap between urban and rural areas has been widening in China? Scholars have analyzed the reasons for the large gap between urban and rural areas from different aspects. From the national perspective, urban-oriented economic policies since the reform and opening up have increased the income gap between urban and rural residents [3] (Yifu Lin, 2007); From the local perspective, the local government excessive pursuit of GDP as the core of appraisal 
system for the local official assessment index [4], ignoring the urbanization alienation behavior, has exacerbated the income gap between urban and rural residents (Xiao Yao, Wu Xiaolong, Liu Zuyun, 2014). Moreover, At the institutional level, the long-standing dualistic structure in China has promoted the one-way transfer of labor force, land, capital and other essential productive factors from rural areas to urban ${ }^{[5]}$, The land non-agriculturalization, the outflow of excellent resources and weak resources promoted the widening income gap between urban and rural residents[6]. In foreign countries, the foreign scholars mainly focus on the research of the industry,the income difference between gender and area because the foreign income distribution gap between urban and rural areas do not so prominent like the one in China due to the basically completed urbanization process.

Although the research literature on the gap between urban and rural is quite rich, the information on the income gap between urban and rural land expansion from the suburban village demolition is less. The influence of village demolition to the income gap between urban and rural areas is considerate, which can not only come close to the reality of rapid urbanization in most of provinces, but also it reflects mechanism of the urban and rural income distribution gap in China. Through the analysis of the mechanism on income gap of new urbanization city, this paper puts forward the convergence path of endogenous urbanization in china, which is designed for avoiding development of "alienation" in the process of urbanization, and promoting social fairness for decision-making in China.

\section{The Influence Mechanism of Urban Expansion on Income Gap between Urban and Rural Areas}

The expansion of urban construction mainly affects the income gap between urban and rural areas through the following four channels.

Local government monopoly on land. Driven by land finance, the government, by virtue of its monopoly of land, buys farmer land at a low price and sells it to developers at a high price for a high monopoly profit.

Contributed to the transfer of land is one of the sources of local government revenue, local governments have realized the accumulation of capital through the transfer of rural land. The more revenue from land transfer obtained by local governments, the better the supply capacity and quality of urban public goods and services, the more obvious welfare gap between urban and rural residents, widening the income gap between urban and rural areas and becoming the "scissors gap" in the initial distribution of land. ${ }^{1}$

With the transformation of suburban villages, urban expansion, industrial agglomeration, urban land and real estate and other resources, are rapid rising in value in the urbanization process, urban residents benefit from more real estate and land value, while the rural government land requisition compensation standards far less than the market value of land itself, especially for the people in in marginal rural areas, there is less return on real estate, land and other financial assets to them, so that the property income of residents in urban and rural areas is hard to be guaranteed by the system. [7]

Unequal social basic public services. Various social public services have not reached equalization. China's insurance system includes urban basic insurance, urban workers basic insurance and new cooperative basic insurance. All three have a big gap in terms of proportion, fund raising, insurance coverage and management methods. As of December 2013, the proportion of migrant workers participating in urban five insurances was $14.3 \%, 24 \%, 16.9 \%, 8.4 \%$ and $6.1 \%$ respectively, with a lower insured rate. ${ }^{2}$ 
Table 1 Comparison of insured rates between urban and rural residents

\begin{tabular}{|c|r|r|r|r|r|}
\hline Insurance type & Pension & $\begin{array}{c}\text { Injury } \\
\text { insurance }\end{array}$ & $\begin{array}{c}\text { medical } \\
\text { insurance }\end{array}$ & $\begin{array}{c}\text { Unemploym } \\
\text { ent } \\
\text { insurance }\end{array}$ & $\begin{array}{r}\text { Maternity } \\
\text { Insurance }\end{array}$ \\
\hline City resident & $99.8 \%$ & $80 \%$ & $99 \%$ & $87.6 \%$ & $85.3 \%$ \\
\hline Migrant Workers & $14.3 \%$ & $24 \%$ & $16.9 \%$ & $8.4 \%$ & $6.1 \%$ \\
\hline
\end{tabular}

"Alienation" of urbanization for rural workers. Due to the fact that the price of urban land is much higher than that of farmland, the scale of demolition and the expansion of urban construction land are obvious. However, the expansion of cities led to the loss of peasants' right to property and income, resulting in a large number of landless peasants. The blind expansion of urban space, the inefficient use of land, the inefficient urban agglomeration have not been fully realized and the waste has been grave ${ }^{3}$. The contradiction of semi-urbanization of the transfer of rural population; the high cost of urbanization, the cost of living, the cost of living space, the cost of intelligence, the cost of social security, the cost of living and the cost of follow-up continue to rise [8]. The fact that "urban disease" and "rural disease" coexist, presenting a pattern of urbanization with high costs and low benefits.

Dual structure of the household registration system. The city attracts talented people and capital with its beautiful environment, rich materials and preferential policies, while the relatively backward rural areas fall into the trap of poverty due to lack of talents and funds. After losing their land, peasants lack the living material security at home due to the high urban house prices, lack of housing and job security to go out to work, and can not afford to go back and stay. The exogenous urbanization mode, further worsening the income gap between urban and rural areas.

\section{Two sector measurement model of urban-rural income gap in the process of new urbanization}

Hypothesis. Hypothesis 1: There are only two economic sectors in the closed economy: the rural sector and the urban sector. The goal is to maximize personal income. Compared to the rural sector, the urban sector is more economically efficient

Hypothesis 2: There are only two employment channels: the city and rural areas. Among them, only the urban labor employment in the city, and wage income is the only source of personal income; rural labor employment in city or countryside, in order to achieve the goal of maximizing the wage income.

Hypothesis 3: Technical progress of the agricultural sector is Ar, the agricultural products Yr is achieved by input labor $\mathrm{Lr}$, land $\mathrm{Tr}$, capital $\mathrm{Kr}$; technological progress rate of city departments is $\mathrm{Au}$, it output non-agricultural products Yu through inputting the city construction land $\mathrm{Tu}$, labor input $\mathrm{Lu}$ capital input $\mathrm{Kr}$. production function, production . Rural department and the city department capital input for the C-D model:

$$
\begin{gathered}
Y_{r}=A_{r} T_{r}^{\alpha_{1}} L_{r}^{\beta_{1}} \\
\nvdash_{u} A_{u} T_{u}{ }^{2 \alpha} L_{u}^{\alpha^{\beta}} K_{u}^{1-\alpha_{2} \beta_{2}}
\end{gathered}
$$

Among them, are rural areas of arable land and labor output elasticity and, decreasing returns to scale, the rural sector, is used with the output elasticity of labor Department of city construction, the output elasticity of urban sector funds, the city Department of constant returns to scale output.

Model derivation and analysis. Assuming that the market prices of agricultural products is L, the relative price of city non-agricultural products is $\mathrm{P}$, the rural sector and city sector wage level are $\mathrm{Wr}$ and $\mathrm{Wu}$, the interest rate of capital is I, according to the hypothesis, to pursuit maximizing the wages is the goal of rural and city labor. 
For the rural sector, the profit maximization function is $\max \left(A T_{r} q_{r}-W L_{r}\right)$

Let $\frac{d \pi_{r}}{d L_{r}}=0$

$$
W_{r}^{*}=A_{r} T_{r}^{\alpha_{1}} \beta_{1} L_{r}^{\beta_{1}-1}=\frac{\beta_{1} Y_{r}}{L_{r}}
$$

For the city sector, the income function is:

$$
\pi_{u}=P A_{u} T_{u}^{\alpha_{2}} L_{u}^{\beta_{2}} K_{u}^{1-\alpha_{2}-\beta_{2}}-W_{u} L_{u}
$$

In order to maximize revenue, it is necessary to $\mathrm{d} \prod \mathrm{u} / \mathrm{Lu}=0$, The optimal wage level corresponding to the maximization of income

$$
W_{u}^{*}=P A_{u} T_{u}^{\alpha_{2}} \beta_{2} L_{u}^{\beta_{2}-1} K_{u}^{1-\alpha_{2}-\beta_{2}}=\frac{\beta_{2} Y_{u}}{L_{u}}
$$

Based on the assumption of 2, the rural labor force can choose the employment department flow freely between urban and rural areas for the pursuit of profit maximization. Assume the existence of a dummy variable, the labor force at home at time $\mathrm{D}=0$, and move into the city to work at time $\mathrm{By}$ neglecting the cost of migration, the maximum average wage income of rural laborers is

$$
\max (\mathrm{W})=\mathrm{P}(\mathrm{D}=0) * \mathrm{Wr}+\mathrm{P}(\mathrm{D}=1) * \mathrm{Wu}
$$

Among them, $\mathrm{E}(\mathrm{W})$ is the expectations of labor income, $\mathrm{P}(\mathrm{D}=0)$ and $\mathrm{P}(\mathrm{D}=1)$ are probability of rural farming and city working for migrant workers respectively. When employment barriers existed between city and rural areas are broken in the new urbanization, and labor force can flow freely between urban and rural areas, the formula 1 is the labor market to achieve market clearing results. On the assumption of equilibrium the total number of social labor, is $\mathrm{N}$, the number of rural labor is $\mathrm{L}$, the total number of urban labor department employment is N-L.

When the employment information in the urban sector is symmetric, the result of each labor force's choice of the employment sector can be regarded as an independent and identically distributed random variable, according to the Bernoulli's large number theorem.

$$
\lim _{L_{r} \rightarrow \infty} P\left\{\left|\sum_{j=1}^{L_{r}} D_{j} / L_{r}-P_{0}\right|<\varepsilon\right\}=1
$$

Eq.(2) shows that when the number of rural labor force is large, the probability convergence of rural labor workers migrate into urban. Because the process of urbanization process in china is accelerating, the $\sum \mathrm{Dj} / \mathrm{Lr}$ approaching to $(\mathrm{N}-\mathrm{L}) / \mathrm{N}$.

The expected income level of the labor force is

$$
E(W)=\frac{L}{N} W_{r}+\frac{N-L}{N} W_{u}=\frac{1}{N}\left(\beta_{1} Y_{r}+\beta_{2} Y_{u}\right)
$$

According to Eq. (5) and Eq. (7), the income ratio of town departments and rural sectors is

$$
\frac{W_{u}}{W_{r}}=\frac{W_{u}}{\frac{L}{N} W_{r}+\frac{N-L}{N} W_{u}}=\frac{\beta_{2}}{\frac{N-L}{N}\left(\beta_{1} \frac{Y_{r}}{Y_{u}}+\beta_{2}\right)}
$$

According to Eq.(8) we can get the following two propositions:

Conclusion 1: when the output gap between urban and rural areas becomes larger, the income gap between urban and rural areas will worsen

Conclusion 2: promoting urbanization and non-agricultural employment of rural labor force can make urban and rural income gap converge.

$$
\frac{W_{u}}{W_{r}}=\frac{1}{\frac{N-L}{N}}=\frac{1}{\frac{\beta_{1} A_{r} T_{r}^{\alpha_{1}} L^{\beta_{1}}}{\beta_{2} A_{u} T_{u}^{\alpha_{2}}(N-L)^{\beta_{2}} K^{1-\alpha 2-\beta 2}}}
$$

The demolition of land expansion means rural land $\operatorname{Tr}$ is reducing while city construction land 
Tu is increasing. Agricultural Land reducing would have negative impact on the gap between urban and rural areas.

Conclusion 3: The expansion of land use is not conducive to shorten the income gap between urban and rural areas.

\section{The Converge Path of Income Gap between Urban and Rural Areas in the Process of New Urbanization}

In order to effectively resolve the problem of the income gap between urban and rural areas, "price differences" must be eliminated the income difference from land expropriation compensation and the original value of housing property. Moreover, to improve the quality of the farmers is also the effective way to achieve convergence of income gap between urban and rural areas. Endogenous urbanization is the urbanization of all the people to participate in, which emphasizes the free flow and coordination of factors between city and rural areas, and focuses on the balanced allocation of factors so as to achieve the convergence of urban-rural income gap.

Promoting labor mobility and reducing wage gap. First, promote the upgrading of the industrial structure, improve the ability to undertake the transfer of urban population, and to support the development of innovative enterprises, small and micro businesses so as to improve the employment ability of new citizen. Second, the transfer of rural population is the regeneration of "human resources" in urban areas, through professional education and training to improve their wage income in service industry and the manufacturing industry, Third, to encourage enterprises to carry out targeted occupation skill training, through the model "doing by learning" to improve the efficiency of human capital, and reduce wage income gap in the city.

Deepening rural land reform and reducing the income gap of property. First, through the reform and legislation of rural land requisition, realize reasonable compensation for the relocation of farmers. According to the State Council Development Research Center of PRC, the land compensation of farmers accounted for only 5\%-10\% of land revenue. Therefore, it is very necessary to improve the land requisition compensation standards and accelerate the reform of land expropriation system .Second, to establish and improve the land transfer system, the formation of professional and intensive use of land, increase land property income of farmers. Third, a series of preferential policies such as tax relief, financial subsidies and lower loan threshold should be taken according to the actual situation of residential housing. Encouraging residential consumption and supporting the private housing property to decrease total property gap between cities and farmers.

Promoting equalization of public services for all the people and promoting the integration of social security in urban and rural areas. First, adhere to the principle of multi center supply, improve the expression mechanism of relocation of farmer needs, the use of modern information technology, constructing a new public interest expression platform, and improve the interest expression ability, the formation of the government led, market participation, third party collaborative public service supply pattern. Second, the residents through the establishment of a special account of the implementation of social security, the excessive absorption of the original "new" security, gradually close to the social security of urban residents, so that the public can enjoy the new urbanization with new education, employment, pension, medical care, housing, social security and a series of welfare Third, the main market ensures market prosperity and efficiency, through the redistribution system, guarantees the development of rights of disadvantaged groups, for the benefit of clarifying the scope of public goods, from finance, taxation, finance, land acquisition to increase support, through the endogenous City, improve the quality and level of urbanization, to achieve urban and rural public service equalization, equalization of living conditions, and finally promote the social security gap between urban and rural areas of convergence.

\section{Conclusions}

The widening income gap brought by exogenous urbanization in the present stage has highlighted 
its shortcomings, such as growth factors difficult to continue development pattern, this will undoubtedly constrain the long-term economic growth caused by the; moreover, the further expansion of the income gap between urban and rural residents will inevitably bring about the unstable factors that affect the investment environment and will be extremely unfavorable to the sustainable development of urbanization

Therefore, the breakthrough the exogenous dilemma of development of urbanization, to deepen the income distribution system and the adjustment of income distribution structure is the premise of improving the rural human capital accumulation, deepening the rural land reform, joint production of the city, urban and rural public service equalization is the key to promote endogenous urbanization.

\section{References}

[1] Zia; Niu Jianlin. Regional economic development and income distribution effects on health differences between Chinese residents [J]. sociological review,2015(3).

[2] Chen Bin, Yifu Lin. Development, urbanization and income gap between urban and rural areas in China [J]. Chinese social sciences, 2013(4):81-102.

[3] Xiao Yao. Urbanization, real estate prices and income gap between urban and rural areas -Empirical Analysis Based on panel data of provinces and autonomous regions of China [J]. financial science,2013(9):100-107

[4] Sun Ninghua. Labor market distortions, efficiency differences and the gap between urban and rural areas, [J]. managing the world, 2009,(9):44-52.

[5]Kuang yuan. The urban-rural income gap in China: an explanation of the [J]. problem of agricultural economy based on factor income stream,2013(2):76-84

[6] Restuccia, D, Dennis Tao, y. Xiaodong, Z. Agriculture and Aggregate Productivity: A Quantitative Cross-county Analysis[J]. Journal of Monetary Economics, 2008,55(2):234-250.

[7] Barro R. Inequality and Growth in a Panel of Countries [J]. Journal of Political Growth,2000,5(1):5-22

[8] Lu Hua, Zhu Wenjun. Evolution, inspiration, structural factors and Countermeasures of urban-rural income and income Bureau [J]. macro-economics research, 2015 (8): 127-133.

\footnotetext{
${ }^{1}$ The government land revenue formula is : Government land revenue = land transfer payments - compensation costs for demolition miscellaneous fees

${ }^{2}$ Information from the World Bank shows that the land area consumed per 10,000 yuan of GDP in China is more than 10 times that of developed countries.

${ }^{3}$ According to the World Bank, the land area per 10,000 yuan of GDP consumed in China is more than 10 times that of developed countries.
} 